\title{
Perbandingan Model Skema Star Dan Snowflake Data Akademik (Studi Kasus UNSIQ Jawa Tengah Di Wonosobo)
}

\author{
Khomsatun $^{1)}$, Kusrini $^{2}$, Andi Suyoto ${ }^{3)}$ \\ ${ }^{123}$ Magister Teknik Informatika Universitas Amikom Yogyakarta \\ Jl. Ringroad Utara, Contong Catur, Sleman, Yogyakarta 55283 Indonesia \\ 1'oonkhaura2@gmail.com, ${ }^{2}$ kusrini@amikom.ac.id, ${ }^{3}$ andi@amikom.ac.id
}

\begin{abstract}
Abstrak
Kebutuhan pihak manajemen Perguruan Tinggi dalam mengambil keputusan dengan cara memberikan informasi yang menghasilkan ringkasan informasi yang akurat dan berguna sebagai masukan untuk menentukan strategi dalam melakukan promosi menjadi tongkat utama dalam penerimaan mahasiswa. Semakin banyaknya mahasiswa semakin jaya pula PerguruanTinggi hinggamemenuhi standar akreditasi. Dalam merancang, pada tahap pembuatan dimensional modeling perancang dihadapkan pada pilihan penggunaan skema yang tepat untuk sistem yang akan dibangunnya. Tahapan ini akan menentukan tingkat efektifitas dan efisiensi sistem. Alasan memilih skema star dan skema snowflakes yang dibandingkan adalah karena keduanya memiliki karakteristik yang bertolak belakang dalam menerapkan hirarki data.Proses pencarian data didapat dengan model skema star dan skema snowflake dengan cara mengukur serta membandingkan hasil dari data warehouse yang disusun berdasarkan parameter row len, blocksize, responsetime dan Cputime. Dilakukan query menggunakan tools phpmyadmin sehingga empat parameter ini akan diketahui dan bisa dibandingkan hasilnya. Dengan hasil yang didapat diharapkan bisa memberikan rekomendasi skema yang terbaik.
\end{abstract}

Kata kunci:Star skema, snowflake skema, pmb

\section{Abstrak}

The need for university management in making decisions by providing information that produces a summary of information that is accurate and useful as input for determining strategies in conducting promotions is the main stick in student admission. The more students, the more prosperous the Higher Education to meet the accreditation standards. In designing, at the stage of making dimensional modeling the designer is faced with the choice of using the right scheme for the system to be built. This stage will determine the level of effectiveness and efficiency of the system. The reason for choosing the star schema and the snowflakes schema that are compared is because both have opposing characteristics in applying the data hierarchy. The process of finding data is obtained by the star schema model and the snowflake schema by measuring and comparing the results of the data warehouse arranged according to the parameters of row len, blocksize, responsetime and cputime. A query is performed using phpmyadmin tools so that these four parameters will be known and the results can be compared. With the results obtained are expected to provide the best scheme recommendations.

Keywords: Star scheme, snowflake scheme, Admission of new students.

\section{PENDAHULUAN}

a. Latar Belakang

Tak hanya dalam dunia sosial dan bisnis tetapi juga dunia pendidikan di mana, informasi tentang dunia pendidikan dibutuhkan dan menjadi salah satu yang wajib untuk diketahui. Tak luput dari perkembangan teknologi, informasi perguruan tinggi sangatlah diperlukan guna menciptakan generasi penerus yang cerdas dan bisa bersaing, masyarakat lebih jeli dan cermat dalam memilih perguruan tinggi yang berkualitas. Persaingan untuk mendapatkan mahasiswa antar perguruan tinggi semakin ketat dan tidak dapat dipungkiri dengan pertumbuhan perguruan tinggi itu sendiri. 
Perguruan tinggi harus melengkapi dirinya untuk dapat bertahan didalam persaingan dan mengembangkan usahanya.

Unsiq Jawa Tengah di Wonosobo merupakan satu-satunya Perguruan Tinggi di kota Wonosobo Jawa Tengah. Berdiri tahun 1988 hingga sekarang UNSIQ sudah menghasilkan alumni yang tersebar di seluruh wilayah Indonesia. Sesuai visi yaitu menciptakan generasi yang Qur'ani dan Madani, UNSIQ sangat perlu adanya perencaan Strategi guna meningktakan bisnisnya dalam memikat hati calon mahasiswa.

Walaupun sudah memiliki website resmi dan banyak sosial media namun UNSIQ perlu menerapkan datawarehouse guna mengetahui arah kebijakan dalampenerimaan Mahasiswa baru.itu sebabnya penelitian ini dibuat agar bisa menerapakan skema mana yang baik dan sesusai diterapkan dalam kasus PMB UNSIQ.

Dalam merancang sebuah data warehouse, pada tahap pembuatan dimensional modeling perancang dihadapkan pada pilihan penggunaan skema yang tepat untuk sistem yang akan dibangunnya. Tahapan ini akan menentukan tingkat efektifitas dan efisiensi sistem. Ada tiga skema yang dapat digunakan yaitu skema star, skema snowflakes dan skema galaxy. Skema star mengikuti struktur bintang, yaitu ada sebuah fact table (table fakta) yang dikelilingi oleh beberapa dimensional table (table dimensi). Skema snowflakes terdiri dari sebuah fact table yang dikelilingi dimensional table yang ada beberapa diantaranya tidak berhubungan langsung dengan fact table melainkan berhubungan dengan dimensional table lainnya. Skema galaxy memiliki beberapa fact table yang memanfaatkan dimensional table dari fact table lainnya.

Hasil pengukuran yang didapat dari model skema star dan skema snowflake dengan pemanggilan querydibandingkan berdasarkan parameter average row len, block size dan response time. Alasan memilih skema star dan skema snowflakes yang dibandingkan adalah karena keduanya memilik karakteristik yang bertolak belakang dalam memandang redundancy data.

\section{b. Rumusan Masalah}

Berdasarkan penjabaran pada latar belakang masalah, maka rumusan masalah pada penelitian ini adalah Sejauh mana pengujian dimensional modeling dengan model skema star dan snowflake Akademik Unsiq Jawa Tengah di Wonosobo.

\section{c. Batasan Masalah}

Batasan Masalah dari penelitian ini adalah Data Akademik Penrimaan Mahasiswa baru UNSIQ Jawa Tengah di Wonosobo.

\section{d. Tujuan Penelitian}

Tujuan dari penelitian ini adalah memberikan rekomendasi skema yang terbaik denga pengukuran parameter average row len, block size dan response time.

\section{e. Tinjauan Pustaka}

1) Samudera, dkk melakukan penelitian berjudul "Merancang Data Mart Perancangan Dashboard Penerimaan Mahasiswa Baru Universitas Muhammadiyah Tangerang". Dalam penelitian menggunakan perancangan BI, OLAP dan dashboard untuk kebutuhan PMB. Tools yang digunakan adalah MsAccess dan Excel Powerpivot. Hasil yang diperoleh adalah implementasi BI dan dashboard kebutuhan PMB. Kelemahannya pengukuran menggunakan star skema dengan data mart yang dibangun bukan merupakan datawarehouse, sehingga perlu dikembangkan.

2) Yaya Sudarya, dkk melakukan penelitiannya berjudul "Aplikasi Data Warehouse Untuk Menunjang Standar 3 Borang Akreditasi Prodi Informatika Universitas Mercu Buana" pada November 2017. Dijelaskan dalam pembuatan laporan borang akreditasi khususnya standar 3 yang dapat mendukung proses pengambilan keputusan strategis untuk tingkat manajemen. Model pengambangan data warehouse yang digunakan dalam penelitian ini adalah model skema star. Hasil yang diperoleh analisis multidimensi dan dapat menghasilkan informasi yang bersifat analis.

3) Metawi Ayub, dkk melakukan penelitian dengan judul "Data Warehouse Sebagai Basis Analisis Data Akademik Perguruan Tinggi" dalam penelitianini dilakukan dengan penerapan semua skema dalam skenario yang berbeda. Hasil Analisis menggunakan model data 
multidimensional dapat dilakukan terhadap data cube yang merupakan implementasi dari skema data mart yang telah dibuat.

4) Faisal, dkk dalam penelitiannya melakukan data warehouse yang terintegrasi dengan OLAP dari data transaksi akademik mahasiswa. Dengan penerapana skema Star . hasil analisa tabel presatasi akademik bagi perguruan tinggi.

5) Yetti, dkk melakukan penelitian dengan judul "Proses Etl (Extract Transformation Loading) Data Warehouse Untuk Peningkatan Kinerja Biodata Dalam Menyajikan Profil Mahasiwa Dari Dimensi Asal Sekolah". Dengan menerapkan star dan Snowflake. Hasil analisa penerapan skema tiap skenario guna pengambilan keputusan masih perlu validasi.

6) Sri Wahyuni dalam penelitiannya menggunakan Snowflake melalui Nine Step Methodology. Hasil analisa Data warehouse yang dihasilkan dapat dimplementasikan dengan sebuah aplikasi untuk menampilkan report-report yang diperlukan. Dalam penelitian ini diimplementasikan dengan PHP

\section{METODE PENELITIAN}

Penelitian ini bersifat Kuantitatif dan digunakan penelitian dan Pengembangan atau Research and Development (R\&D). Dilakukan rangkaian proses atau langkahlangkah dalam rangka mengembangkan data warehouse menggunakan modeling multidimensional dengan dua skema sekaligus.

Proses Analisis dilakukan terhadap data yang sudah ada dari website Penerimaan Mahasiswa Baru Unsiq Jawa Tengah di Wonosobo dari tahun 2016-2019 dan studi pustaka untuk mendapatakan laporan yang sesuai dengan kebutuhan. Data yang didapat adalah dari pengolahan website yang digunakan yang selanjutnya diolah dengan query dan diukur performa masing-masing skema.

Perbandingan Star Schema dan Snowflake dilakukan dengan pengujian query dari tiap skema dan diuji dengan tiap skenario pengujian. Skenario yang diujikan Penerimaan Mahasiswa baru yang selanjutnya dari masing-masing hasil query diukur performa Average row length, Block Size, Responsive Time dan dibandingkan utnuk mendapatakan kesimpulan mana yang lebih baik dari kedua skema.

\section{TINJAUAN PUSTAKA \\ a. DBMS}

Menurut Connolly dan Begg (2010:66), Database Management System adalah sebuah sistem software yang memungkinkan pengguna untuk mendefinisikan, membuat, memelihara, dan mengontrol akses ke database.

\section{b. Data Warehouse}

Menurut Nugroho (2004), data warehouse adalah kumpulan data yang berorientasi subjek, terintegrasi, memiliki dimensi waktu serta merupakan koleksi tetap (non-volatile) yang digunakan dalam mendukung proses pengambilan oleh para manajer tingkat puncak

Alur proses Data Warehouse terbentuk adanya sistem On Line Transaction Processsing (OLTP) yaitu saat data diinputkan dalam database, dan setelah proses ETL dilakukan,. Proses lanjutan dari Data Warehouse adalah proses penggunaan data tersebut yang disebut sebagai sistem On Line Analytical Processsing (OLAP) [Ponniah,2010]

\section{c. On-line Transaction Processing (OLTP)}

Menurut Rainer and turban (2009): "OLTP (Online Transaction Processing) adalah pernrosesan transaksi bisnis secara online langsung setelah transaksi itu teljadi". Menurut Connolly and Begg (2010) "OLTP adalah sebuah sistem yang dirancang untuk menangani pemrosesan transaksi tingkat tinggi, dengan transaksi yang secara umum membuat perubahan kecil pada data operasional organisasi, yang dibutuhkan oleh organisasi untuk menangani operasi seharihari"

\section{d. Online Analitical Prosesing (OLAP)}

adalah teknologi yang memproses daata di dalam database dalam struktur multidimensi, menyediakan jawaban yang cepat untuk query dan analisis yang kompleks. Data yang disajikan biasanya merupakan suatu fungsi agregasi seperti summary, max, min, average dan lain-lain.

\section{e. Extract, Transform, Loading Data (ETL)}

Menurut Rainardi (2008), ETL adalah suatu proses mengambil dan mengirim data 
dari sumber data ke data warehouse. Dalam proses pengambilan data, data harus bersih agar didapat kualitas data yang baik. Contohnya ada nomor telepon yang invalid, ada kode buku yang tidak eksis lagi, ada beberapa data yang null, dan lain sebagainya. Pendekatan tradisional pada proses ETL mengambil data dari data sumber, meletakkan pada staging area, dan kemudian mentransformasi dan meng-load ke data warehouse

\section{f. Dimensionality Modelling}

Menurut Connolly dan Begg (2010:1227), Dimensionality Modeling adalah sebuah teknik desain logika yang bertujuan untuk menampilkan data dalam bentuk standar, intuitif yang memungkinkan akses cepat.

Dimensionality Modeling menggunakan konsep model Entity-Relationship (ER) dengan beberapa batasan penting. Setiap model dimensi terdiri dari satu tabel dengan satu composite primary key yang disebut fact table dan memiliki kumpulan dari tabel yang lebih sederhana yang disebut tabel dimensi (Dimension Table). Tiap tabel dimensi memiliki primary key (non composite) yang akan berkorespondensi tepat satu dengan komponen pada composite key dalam fact table.

\section{g. Star Schema}

Skema ini mengikuti bintang, dimana terdapat satu tabel fakta di pusat bintang dengan beberapa tabel dimensi yang mengelilinginya. Semua tabel dimensi berhubungan langsung dengan tabel fakta. Primary key pada tabel dimensi akan menjadi key pada tabel fakta memiliki kombinasi key dari tabel dimensi. Adapun kelebihan model ini adalah simpel dan mudah dipahami, hasil query juga lebih cepat. Akan tetapi model ini boros dalam tempat penyimpanan.

\section{h. Snowflake}

Model snowflake Schema merupakan perluasan dari star sheme dimana ia juga mempunyai satu atau lebih dimensi. Hanya saja pada snowflake Schema, tabel yang berelasi pada fact table hanya tabel dimensi utama saja, sedangkan tabel yang lain dihubungkan pada tabel dimensi. Model snowflake Schema hampir seperti teknik normalisasi.

\section{i. MySQL}

Menurut Kadir (2009:2), "MySQL adalah sebuah software open source yang digunakan untuk membuat sebuah database". Sistem manajemen database SQL open source yang paling popular. Tujuan utama dari manajemen database MySQL adalah kecepatan dan kinerja. Database server ini "sangat cepat, terpercaya, terukur dan mudah digunakan."

\section{HASIL DAN PEMBAHASAN}

a. Perolehan data

Tampilan data yang didapat dari

UNSIQ Jawa Tengah adalah sebagai berikut :

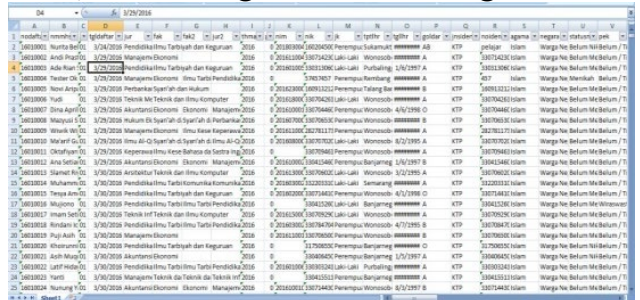

Gambar 1. data yang didapat dari UNSIQ Jawa Tengah

Berisikan data yang sangat komplek dan signifikan untuk proses akademik selanjutnya, hanya belum adanya identifikasi yang mudah diterima managerial karena menggunakan kode yang dimengerti oleh bagian informasi sistem saja.

b. Perancangan data mart dengan skema Star Dibuat menjadi 1 tabel fact dan 6 tabel dimensi

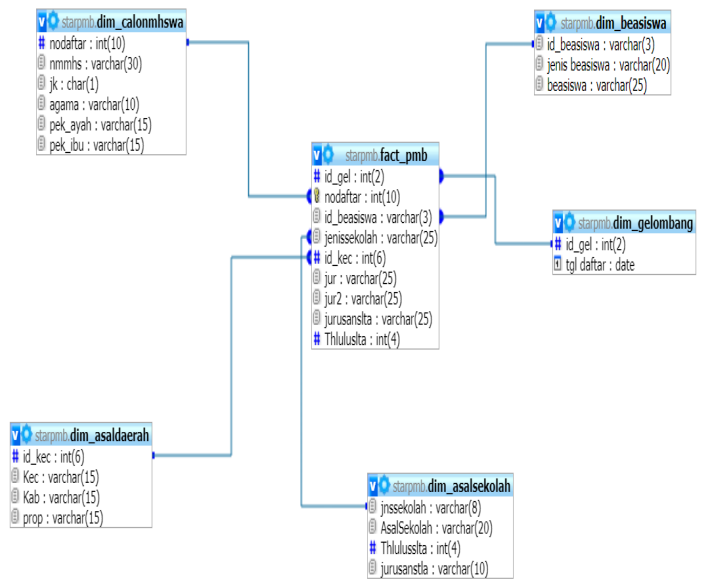

Gambar 2. Skema star PMB 
c. Perancangan dengan Snowflake

Dengan 8 tabel dimensi dan 2 tabel fact yang telah dinormalisasi.

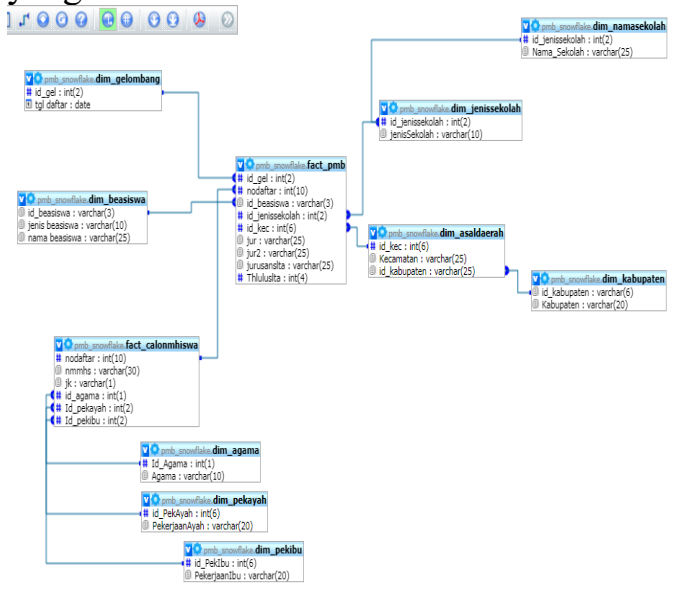

Gambar 2. Snowflake skema PMB

\section{d. Pengujian}

Pengujian penelitian ini memiliki beberapa parameter yang diujiakan antara lain

1. Block Size

disebut catatan fisik, adalah urutan byte atau bit, biasanya berisi sejumlah seluruh catatan, memiliki panjang maksimum, ukuran blok. Ini menunjukkan ukuran tabel di sql dari tiap skema yang diujikan guna pembandingan

2. Average Row lenght

Panjang rata-rata baris pemanggilan perintah query.

3. Respontime

Waktu pemanggilan tiap pengujian skenario pelaporan, didapatkan dengan query yang berbeda guna membandingkan waktu tercepat dan efisien dalam pemanggilan data.

4. Cputime

Dalam kata lain adalah waktu proses, artinya waktuyang digunakan unit pemrosesan pusat untuk memproses perintah dari program atau system operasi

\section{e. Block Size}

Select@@query_alloc_block_size

Skema awal hasil yang didapatkan sama yaitu berupa angka 8192 dengan eksekusi waktu pemanggilanadalah 0.0370 detik, pada skema star adalah 0.0010 detik,sedangkan Snowflakedengan waktu pemanggilan 0.0020 detik. Sehingga Star lebih mendominasi keunggulannya.

Sedangkan untuk Sedangkan size tiap tabel didapatkan dengan query yang sam hanya berbeda di nama skema dan dihasilkan size tiap skema. Skema awal didapatkan 97 kolom yang membuat size lebih banyak dibutuhkan yaitu 9.05 MB dengan waaktu eksekusi yang lama.

Star skema

SELECT table name "NamaTable", table rows "Jumlah Record", round(((data_length + index_length)/1024/102 4),2) "TableSize

(MB)" FROM information_schema.TABLES WHERE $t$ able schema $=$ "star"

Tabel 1. size tabel star skema

\begin{tabular}{|l|c|c|}
\hline Nama Table & Jumlah Record & $\begin{array}{c}\text { Table Size } \\
\text { (MB) }\end{array}$ \\
\hline dim_asaldaerah & 1271 & 0.09 \\
\hline dim asalsekolah & 2791 & 0.2 \\
\hline dim beasiswa & 9 & 0.02 \\
\hline dim calonmhiswa & 9213 & 0.5 \\
\hline dim gelombang & 3 & 0.02 \\
\hline fact pmb & 8987 & 2.25 \\
\hline Total & 22274 & 3.08 \\
\hline
\end{tabular}

Menampilkan baris 0 - 5 (total 6, Pencarian dilakukan dalam 0.0020 detik.)

Size snowflake skema

SELECT table name "NamaTable", table rows "Jumlah Record", round( ((data_length + index_length)/1024/102 4),2)"Table Size

(MB)" FROM information schema.TABLES WHERE $\mathrm{t}$ able_schema $=$ "snowflake"

Tabel 2. size tabel snowflake skema

\begin{tabular}{|l|l|l|}
\hline NamaTable & $\begin{array}{l}\text { Jumlah } \\
\text { Record }\end{array}$ & Table Size (MB) \\
\hline dim_agama & 0 & 0.02 \\
\hline dim_asaldaerah & 1271 & 0.13 \\
\hline dim_beasiswa & 9 & 0.02 \\
\hline dim_gelombang & 3 & 0.02 \\
\hline dim_jenissekolah & 9 & 0.02 \\
\hline dim_kabupaten & 183 & 0.02 \\
\hline dim_namasekolah & 2791 & 0.25 \\
\hline dim_pekayah & 56 & 0.02 \\
\hline dim_pekibu & 32 & 0.02 \\
\hline fact_calonmhiswa & 9018 & 2.06 \\
\hline fact_pmb & 8970 & 2.14 \\
\hline Total & 22342 & 4.72 \\
\hline
\end{tabular}

Menampilkan baris 0 - 10 (total 11, Pencarian dilakukan dalam 0.0030 detik.). Dilihat dari performa Block Size, didapatkan star skema dengan size $3.08 \mathrm{MB}$ sedangkan Snoflake lebih banyak membutuhkan Size dengan angka 4.72MB.

\section{f. Skenario Pengujian}

Dari data Penerimaan dibutuhkan data pendaftar lengkap, yang menyebutkan alamat, asal sekolah, agama, jurusan sekolah, tahun lulus, pekerjaan orangtua, guna merencakan strategi pemasaran Kampus 
Universitas Sains al-Qur'an Jawa Tengah di Wonosobo untuk mengetahui biodata komplit tiap calon mahasiswa. Dengan skenario tersebut didapatkan query pemanggilan tiap skema sebagai berikut :

Tabel 3. Query Pemanggilan Tiap Skema

\begin{tabular}{|c|c|c|}
\hline Ket & star & Snowflake \\
\hline $\begin{array}{c}\text { Data } \\
\text { pendaft } \\
\text { ar } \\
\text { keselur } \\
\text { uhan }\end{array}$ & $\begin{array}{l}\text { SELECT } \\
\text { fp.tgl_daftar, } \\
\text { fp.nodaftar, } \\
\text { dc.nmmhs, } \\
\text { da.Nama_Sekolah, } \\
\text { dd.Kecamatan, } \\
\text { dd.Kabupaten, } \\
\text { db.nama_beasiswa, } \\
\text { dc.id_agama, } \\
\text { dc.Id_pekayah, } \\
\text { dc.Id_pekibu, fp.jur, } \\
\text { fp.jur2, fp.Thluluslta } \\
\text { FROM fact_pmb as } \\
\text { fp } \\
\text { JOIN } \\
\text { dim_calonmhiswa as } \\
\text { dc } \\
\text { fp.nodaftar=dc.noda } \\
\text { ftar } \\
\text { JOIN ON } \\
\text { dim_asalsekolah as } \\
\text { da } \\
\text { fp.AsalSekolah=da. } \\
\text { Asalsekolah } \\
\text { JOIN } \\
\text { dim_asaldaerah as } \\
\text { dd } \\
\text { fp.id_kec=dd.id_kec } \\
\text { JOIN dim_beasiswa } \\
\text { as db ON } \\
\text { fp.id_beasiswa=db.i } \\
\text { d_beasiswa } \\
\text { ORDER } \\
\text { fp.tgl_daftar DESC }\end{array}$ & $\begin{array}{l}\text { SELECT fp.tgl_daftar, } \\
\text { fp.id_gel, fp.nodaftar, } \\
\text { fc.nmmhs, } \\
\text { dn.Nama_Sekolah, } \\
\text { dd.Kecamatan, } \\
\text { dk.Kabupaten, } \\
\text { db.nama_beasiswa, } \\
\text { da.Agama, } \\
\text { dp.PekerjaanAyah, } \\
\text { di.PekerjaanIbu, fp.jur, } \\
\text { fp.jur2,fp.jurusanslta, } \\
\text { fp.Thluluslta FROM } \\
\text { 'fact_pmb`as fp } \\
\text { JOIN fact_calonmhiswa } \\
\text { as fc ON } \\
\text { fp.nodaftar=fc.nodaftar } \\
\text { JOIN dim_namasekolah } \\
\text { as dn ON } \\
\text { fp.AsalSekolah=dn.id_se } \\
\text { kolah } \\
\text { JOIN dim_asaldaerah as } \\
\text { dd ON } \\
\text { fp.id_kec=dd.id_kec } \\
\text { LEFT JOIN } \\
\text { dim_kabupaten as dk } \\
\text { ON } \\
\text { dd.Kabupaten=dk.id_kab } \\
\text { upaten } \\
\text { JOIN dim_beasiswa as } \\
\text { db ON } \\
\text { fp.id_beasiswa=db.id_be } \\
\text { asiswa } \\
\text { LEFT JOIN dim_agama } \\
\text { as da ON } \\
\text { fc.id_agama=da.Id_Aga } \\
\text { ma } \\
\text { LEFT JOIN } \\
\text { dim_pekayah as dp ON } \\
\text { fc.Id_pekayah=dp.id_Pe } \\
\text { kAyah } \\
\text { LEFT JOIN dim_pekibu } \\
\text { as di ON } \\
\text { fc.Id_pekibu=di.id_PekI } \\
\text { bu } \\
\text { ORDER BY } \\
\text { fp.tgl daftar DESC } \\
\text { didal }\end{array}$ \\
\hline$A R L$ & 443 & 704 \\
\hline $\begin{array}{l}\text { Respon } \\
\text { time }\end{array}$ & $0.0001 \mathrm{sec}$ & $0.0002 \mathrm{sec}$ \\
\hline
\end{tabular}

Dari hasil pengujian skema star lebih bagus, karena menunjukkan Eksekusi baris lebih sedikit dan eksekusi waktu pemanggilan 50\% dibawah Snowflake skema.

Data Penerimaan Mahasiswa baru, diperlukan menampilkan data calon mahasiswa yang berasal dari sekolah mana, guna merencakan strategi pemasaran Kampus Universitas Sains al-Qur'an Jawa Tengah di Wonosobo untuk mengadakan kerjasama ataupun meet and greet kampus. Dengan skenario tersebut didapatkan query pemanggilan tiap skema sebagai berikut :

Tabel 4. Query Pemanggilan Tiap Skema

\begin{tabular}{|c|c|c|}
\hline Ket & Star & Snowflake \\
\hline $\begin{array}{l}\text { Jumlah } \\
\text { Pendafta } \\
\text { r } \\
\text { berdasar } \\
\text { kan } \\
\text { nama } \\
\text { sekolah }\end{array}$ & $\begin{array}{l}\text { SELECTdn.Nama_Sek } \\
\text { olah, count(*) as } \\
\text { Jumlah_Pendaftar } \\
\text { FROM ‘fact_pmb` as } \\
\text { fb } \\
\text { JOIN dim_asalsekolah } \\
\text { as dn ON } \\
\text { fb.AsalSekolah=dn.Asa } \\
\text { lsekolah } \\
\text { GROUP BY } \\
\text { fb.AsalSekolah } \\
\text { ORDER BY } \\
\text { Jumlah_Pendaftar } \\
\text { DESC }\end{array}$ & $\begin{array}{l}\text { SELECT } \\
\text { dn.Nama_Sekolah, } \\
\text { count(*) as } \\
\text { Jumlah_Pendaftar } \\
\text { FROM `fact_pmb } \\
\text { as fb } \\
\text { JOIN } \\
\text { dim_namasekolah as } \\
\text { dn ON } \\
\text { fb.AsalSekolah=dn.i } \\
\text { d_sekolah } \\
\text { GROUP BY } \\
\text { fb.AsalSekolah } \\
\text { ORDERBY } \\
\text { Jumlah_Pendaftar } \\
\text { DESC }\end{array}$ \\
\hline ARL & 189 & 188 \\
\hline $\begin{array}{l}\text { Responti } \\
\text { me }\end{array}$ & $0.0001 \mathrm{sec}$ & $0.0001 \mathrm{sec}$ \\
\hline Hasil & $\begin{array}{l}\text { Ditemukan } \\
\text { sekolah }\end{array}$ & Ditemukan 1830 \\
\hline
\end{tabular}

Dari hasil pengujian skema Snowflake lebih bagus dikarenakan eksekusi waktu pemanggilan sama, tetapi Eksekusi baris lebih sedikit dan hasil yang didapatkan juga lebih sedikit. Ini dikarenakan di star skema masih terdapat redudancy data, sedangkan di Snowflake sudah dinormalisasi.

Pengujian query pemanggilan daftar 10 Kabupaten teratas yang menyumbang calon mahasiswa Unsiq Jawa Tengah di Wonosobo, dengan asumsi akan dijadikan patokan papan reklame guna promosi Penerimaan Mahasiswa Baru. Dengan permintaan yang tertera, maka query yang digunakan adalah sebagai berikut:

Tabel 5. Query Yang Digunakan

\begin{tabular}{|l|l|l|}
\hline Ket & Star & Snowflake \\
\hline Query & SELECT & SELECT \\
& asal.Kabupaten & kab.Kabupaten, \\
& count(nodaftar) as \\
& count(nodaftar) & Jumlah_pendaftar \\
as & FROM fact_pmb AS \\
& Jumlah_pendaf & fp JOIN \\
& tar FROM & dim_asaldaerah AS \\
& fact_pmb AS & asal ON \\
fp_JOIN & fp.id_kec=asal.id_kec \\
& dim_asaldaerah & LEFT JOI N \\
& AS asal ON & dim_kabupaten AS kab \\
& fp.id_kec=asal. & ON \\
& id_kec GROUP & asal.Kabupaten=kab.id \\
& BY & kabupaten GROUP \\
& asal.Kabupaten & BY asal.Kabupaten \\
& ORDER BY & ORDER BY \\
& Jumlah_pendaf & Jumlah_pendaftar \\
& tar DESC & DESC LIMIT 10 \\
& LIMIT 10 & \\
&
\end{tabular}




\begin{tabular}{|l|l|l|}
\hline & & \\
\hline ARL & 195 & 260 \\
\hline $\begin{array}{l}\text { Respont } \\
\text { ime }\end{array}$ & $0.0220 \mathrm{sec}$ & 0.0167 \\
\hline
\end{tabular}

Dari hasil pengujian Star lebih bagus dalam row Length, namun tertinggal dengan waktu eksekusi yang lebih lama yaitu 0.0220 second.

Dari hasil skenario pemanggilan query didapatkan hasil pengujian dengan eksekusi baris ditunjukkan tabel sebagai berikut :

Tabel 6. Hasil Pengujian

Dengan Eksekusi Baris

\begin{tabular}{|l|l|l|}
\hline \multicolumn{1}{|c|}{ Skenario } & $\begin{array}{c}\text { Eksekusi } \\
\text { baris }\end{array}$ & \multicolumn{1}{|c|}{} \\
\cline { 2 - 3 } & star & snowflake \\
\hline $\begin{array}{l}\text { calon mahasiswa yang } \\
\text { berasal dari sekolah mana }\end{array}$ & 186 & 185 \\
\hline $\begin{array}{l}\text { Data lengkap Calon } \\
\text { Mahasiswa }\end{array}$ & 443 & 704 \\
\hline $\begin{array}{l}\text { Daftar Penerima } \\
\text { BeassiwaTahfidz }\end{array}$ & 325 & 326 \\
\hline 10 Kabupaten terbanyak & 195 & 261 \\
\hline
\end{tabular}

Star skema lebih memiliki eksekusi baris yang cenderung lebih sedikit dalam pemanggilan tiap skenario query.

Dari hasil skenario pemanggilan query didapatkan hasil pengujian dengan eksekusi waktu ditunjukkan tabel sebagai berikut :

Tabel 7. Hasil Pengujian

Dengan Eksekusi Waktu

\begin{tabular}{|l|l|l|}
\hline Skenario Pengujian & Star & snowflake \\
\hline $\begin{array}{l}\text { calon mahasiswa yang } \\
\text { berasal dari sekolah mana }\end{array}$ & 0.0001 & 0.0001 \\
\hline $\begin{array}{l}\text { Data lengkap Calon } \\
\text { Mahasiswa }\end{array}$ & 0.0001 & 0.0002 \\
\hline $\begin{array}{l}\text { Daftar Penerima } \\
\text { BeassiwaTahfidz }\end{array}$ & 0.0060 & 0.0067 \\
\hline 10 Kabupaten terbanyak & 0.0022 & 0.0167 \\
\hline
\end{tabular}

Dan ditampilkan dengan grafik yang semakin meningkat pada Snowflake Skema, sehingga Star lebih memerlukan waktu eksekusi yang lebihpendek.

\section{g. Cpu Time}

Dengan dasar query tersebut diatas dilakukan juga denga Cpu yang berbeda digunakan untuk melihat sejauhmana hasil pengujian time yang dihasilkan akan berbeda. Dengan Ini artinya waktu yang dibutuhkan dalam perbandingan skema pengujian juga akan berbeda. Maka dalam pengujian digunakan cpu yang berbeda, spek cpu yang digunakan dalam perbandingan adalah sebagai berikut :
Cpu 1

Window 7

Intel (R) Core TM 2

CPU T5500@

$1,666 \mathrm{GHz}$

Ram 2,50 GB

32 bit
Win 10

Cpu 2

Intel core TM CPU @

$1.90 \mathrm{GHz}$

$6 \mathrm{~GB}$

64 bit
Tabel 8. Hasil Pengujian

\begin{tabular}{|l|l|l|l|l|}
\hline \multirow{2}{*}{\multicolumn{1}{|c|}{ skenario }} & \multicolumn{2}{|c|}{ cpu 1- win 7 } & \multicolumn{2}{c|}{ cpu 2- win 10 } \\
\cline { 2 - 5 } & star & snowflake & star & snowflake \\
\hline $\begin{array}{l}\text { calon mahasiswa } \\
\text { yang berasal dari } \\
\text { sekolah mana }\end{array}$ & 0.0001 & 0.0001 & 0,0002 & 0,0003 \\
\hline $\begin{array}{l}\text { Data lengkap } \\
\text { Calon } \\
\text { Mahasiswa }\end{array}$ & 0.0001 & 0.0002 & 0.0001 & 0.0002 \\
\hline $\begin{array}{l}\text { Daftar Penerima } \\
\text { BeassiwaTahfidz }\end{array}$ & 0.0002 & 0.0001 & 0,0130 & 0,0060 \\
\hline $\begin{array}{l}\text { 10 Kabupaten } \\
\text { terbanyak }\end{array}$ & 0.022 & 0.0167 & 0,0060 & 0,0060 \\
\hline
\end{tabular}

Dari hasil pemanggilan query didapatkan eksekusi waktu yang berbeda pada $\mathrm{Cpu}$ yang berbeda. Window 7 lebih cepat dalam eksekusi perintah query dibandingkan dengan window 10 . Ditemukan pula waktu yang berbeda dengan scenario yang sama. Ini dikarenakan prosesor atau kinerja $\mathrm{Cpu}$ itu tersendiri,sehingga disimpulkan pengujian harus dalam waktu yang hamper bersamaan dan dalam performa cpu yang sama.

Hasil pengukuran performa Respontime star skema Window 7 lebih memerlukan waktu eksekusi yang sedikit dibandingkan window 10.

Hasil pengukuran performa Respontime Snowflake skema Window 7 lebih memerlukan waktu eksekusi yang sedikit dibandingkan window 10.

\section{KESIMPULAN DAN SARAN \\ a. Kesimpulan}

Berdasarkan hasil pengujian performa dimensional modeling datawarehouse star skema dan Snowflakedata akademik studi kasus di UNSIQJawa Tengah di Wonosobo, maka penulis menarik kesimpulan sebagai berikut :

1. Skema awal memiliki size sebesar 9.50 $\mathrm{MB}$, dalam pegujianStar skema memiliki kolom yang lebih sedikit, ukuran lebih kecil dan size tabel yang cenderung lebih kecil yaitu 3.08 MB dibandingkan dengan snowflake yang memiliki tabel 
dimensi turunan dengan size table 4.72 $\mathrm{MB}$, sehingga jika dilihat dari performa Size Star lebih efektif.

2. Block Size yang dihasilkan sama antara star dan snowflake yaitu 8192 .

3. Pengujian Query dalam skenario yang berbeda akan mendapatkan hasilyang berbeda pula, skema star lebih memerlukan waktu pemanggilan yang singkat dibandingkansnowflake.

4. Pengujian dasar query yang dilakukan dalam performa Average Row Length lebih sedikit Star dibandingkan dengan Snowflake, terlihat dalam tabel dan grafik, sehingga jika dilihat eksekusi baris Star lebih unggul.

5. Pengujian pada cpu yang berbeda menghasilkan respontimeyang berbeda, hasil yang berbeda juga didapat ketika pemanggilan pada waktu yang berbeda. Dalam penelitian ini Windows 7 lebih memerlukan waktu yang sedikit dibandingkan Window 10.

6. Pengujian starskema dan snowflake dengan melihat dari performa yang diujiakan yaitu Row Lenght, Respontime, Block Size dan cpu time pada penerimaan Mahasiswa baru Unsiq Jawa Tengah di Wonosobo lebih dimenangkan oleh star skema,jika dilihat dari eksekusi baris dan eksekusi waktu pemangilan.

\section{b. Saran}

Dengan perkembangan sistem informasi penerimaan Mahasiswa baru Unsiq Jawa Tengah di Wonosobo diharapkan dapat menjadi bahan pertimbangan untuk peneliti atau pengembang sistem selanjutnya, yang diataranya :

1. Penerapan skema sangat diperlukan dalam penerapan sistem akademik Penerimaan Mahasiswa baru guna strategi pengambilan keputusan dalam promosi maupun pengembangan sistem.

2. Skema Star sesuai diterapkan dalam Data Penerimaan Mahasiswa Baru Unsiq Jawa Tengah khususnya Untuk pengembangan sistem informasi penerimaan siswa baru diharapkan untuk mengembangkan design web agar lebih menarik dari yang telah dibangun.

3. Untuk peneliti selanjutnya diharapkan dapat memberikan rekomendasi skema yang terbaik dalam akademik yang lainnya.

4. Untuk penelitiam selanjutnya diharapkan membandingkan lebih dari 2 skema dengan beberapa cpu dalam waktu yang bersamaan.

\section{REFERENSI}

Samudera Dipa Legawa, Ignaitus Joko Dewanto, Henderi, Ferry Sudarto. (2017). Merancang Data Mart Perancangan Dashboard Penerimaan Mahasiswa Baru Universitas Muhammadiyah Tangerang. Seminar Nasional Multi Disiplin Ilmu. Volume.1.

Yaya Sudarya Triana, Anggito Susilo.(2017).

Aplikasi Data Warehouse Untuk Menunjang Standar 3 Borang Akreditasi Prodi Informatika Universitas Mercu Buana,.Jurnal Ilmiah Fifo,9(2).

Mewati Ayub, Tanti Kristanti , Maresha Caroline.(2013).Data Warehouse Sebagai Basis Analisis Data Akademik Perguruan Tinggi.Seminar Nasional Teknologi Informasi

Faisal Rahutomo, Cahya Rahmad, Muhammad Bisri Musthafa, Ngatmari.(2019).Desain Skema Data Warehouse PDDIKTI sebagai Pendukung Keputusan Perguruan Tinggi Jurnal Inovtek Polbeng-Seri Informatika, 4(1).

Yetli Oslan dan Harianto Kristanto.(2019).Proses Etl (Extract Transformation Loading) Data Warehouse Untuk Peningkatan Kinerja Biodata Dalam Menyajikan Profil Mahasiwa Dari Dimensi Asal Sekolah Studi Kasus: Biodata Mahasiswa Ukdw Research Fair Unisri 2019.3(1).

Sri Wahyuni.(2018).Data Warehouse Perguruan Tinggi Dengan Model Snowflake Schema Dan Nine Step Methodology Studi Kasus Stmik Cikarang,Jurnal Informatika SIMANTIK.3(1).

Nugroho, Adi. (2004). Konsep Pengembangan Sistem Basis Data. Bandung: Penerbit Informatika.

Ponniah, Paulraj.(2010). Data Warehousing Fundamentals for IT Professional 2nd ed, John Wiley \& Sons Inc.

Rainer, R.K and Efraim Turban.(2009). Introduction to Information System: Enabling and Transforming Business. USA: John \& bSons, 
Connolly, Thomas and Begg, Carolyn. (2010).

Database Systems A Practical Approach

to Design, Implementation, and

Management Fifth Edition. Boston:

Pearson Education.

Kadir, Abdul.(2008).Tuntunan Praktis Belajar Database Menggunakan MySQL. Yogyakarta: Andi.

Paulraj Ponniah.(2001).Data Warehousing Fundamentals: A Comprehensive Guide for IT Professionals. 